Gut, 1961, 2, 158

\title{
A clinical appraisal of the treatment of chronic duodenal ulcer by vagotomy and gastric drainage operation
}

\author{
W. GERALD AUSTEN ${ }^{1}$ AND HAROLD C. EDWARDS \\ From King's College Hospital, London
}

SYNOPSIS The authors have followed up 100 patients upon whom a vagotomy plus a drainage operation was performed for chronic duodenal ulceration by one of them (H.C.E.) at King's College Hospital during the 11-year period 1948-1958.

\section{DATA}

All the patients entered the hospital because of chronic duodenal ulceration. Eighty-one were men and 19 were women. Their average age at the time of operation was 39.8 years, with a range of 14 to 74 years, and the length of symptoms before surgery averaged $10 \cdot 2$ years, with a range of one to 30 years. Previous ulcer complications had occurred in 37 of the patients as follows:-Bleeding (16), obstruction (13), and perforation (8). Vagotomy was followed by gastroenterostomy in 90 patients and by pyloroplasty in 10 (Table I).

All patients underwent gastric acid studies before operation, including resting free and total acid determinations and insulin response (Hollander, 1946, 1948). These tests were then repeated postoperatively, usually within two weeks of operation, or occasionally a number of months later, at a time of a re-admission. The acid studies of a few of the cases are not reported, either because the tests were deemed to be unsatisfactory, or because the records are lost.

\section{OPERATIVE TECHNIQUE}

A right paramedian incision is made from the left xphisternocostal angle to the umbilicus, and the diagnosis of duodenal ulceration confirmed. The left lobe of the liver is retracted upwards and to the right (there is rarely need to divide the coronary ligament) and the vagus nerves exposed by incising the peritoneum and fascia propria over the lower end of the oesophagus, beginning the incision to the left of the oesophagus. Further exposure is obtained by gentle traction on a length of Paul's tubing passed

${ }^{1}$ Present address: The National Institutes of Health, Bethesda 14, Maryland, U.S.A.
TABLE I

SUMMARY OF RESULTS

$\begin{array}{lc}\text { Cases } & 100 \\ \text { Male } & 81 \\ \text { Females } & 19 \\ \text { Mean age (yr.) } & 39 \cdot 8(14-74) \\ \text { Mean length of symptoms (yr.) } & 10 \cdot 2(1-30) \\ \text { Total ulcer complications before surgery } & 37 \% \\ \text { Bleeding } & 16 \% \\ \text { Obstruction } & 13 \% \\ \text { Perforation } & 8 \% \\ \text { Pre-operative acid studies } & \\ \text { Resting free acid (mEq./1.) in } 89 \text { cases } & 46(0-110) \\ \text { Insulin response in 88 cases } & 87 \text { positive } \\ \text { Type of operation performed with vagotomy } & \\ \text { Pyloroplasty and gastroenterostomy } & 90 \\ \text { Pyloroplasty } & 10 \\ \text { Complications and mortality (\%) } & \\ \text { Severe } & 1 \\ \text { Mild } & 15 \\ \text { Mortality } & 1 \\ \text { Post-operative acid studies } & \\ \text { Resting free acid (mEq./1.) in } 82 \text { cases } & 10(0-60) \\ \text { Insulin response in 82 cases } & 13 \text { positive } \\ \text { Mean length of follow-up (yr.) } & 4.9(2-11) \\ \text { Success of surgery in patients' opinion } & 96 \% \text { yes } \\ \text { Full day's work } & 96 \% \text { yes } \\ \text { Recurrent ulcer } & 5 \% \\ \text { Weight change (\%) } & \\ \text { Gain } & 23 \\ \text { Loss } & 13 \\ \text { Gastrointestinal symptoms (\%) } & \\ \text { Dumping } & 15 \\ \text { Diarrhoea } & \\ \text { Other } & \\ & \\ & \end{array}$

around the oesophagus. The left (anterior) vagus is usually visible, but on occasion needs to be located with the finger. The right (posterior) branch is located manually and brought into view by hook retraction. One to one and a half inches of each 
nerve is resected, and both proximal and distal ends ligated with fine thread. Any residual smaller branches are recognized by finger palpation, and divided without ligature. Considerable time and care is taken to ensure that all vagal nerve tissue is divided, although, as will be seen, this was not always achieved.

The gastroenterostomy is made just posterior to the greater curvature of the stomach, and placed as near to the pylorus as is technically suitable, and the stoma made large enough to admit three fingers. It is isoperistaltic, with no loop. If a pyloroplasty is employed as the drainage procedure, an adequate stoma is ensured by making the incision through the antro-duodenal wall two inches in length, and centred at the pylorus. The patients do not normally receive intravenous therapy or blood replacement during or after operation.

After discharge from hospital all the patients have been seen at three-monthly intervals in the outpatient surgical clinic during the first year, and at least once during the second year. From then on follow-up has continued in a somewhat haphazard way, sometimes by mail and sometimes by clinic visits. At the time of this evaluation all patients were sent a questionnaire. In addition, 39 of the patients were interviewed.

\section{COMPLICATIONS AND MORTALITY OF SURGERY}

Complications after operation were uncommon (Table II). There was one case of pulmonary embolus,

TABLE II

\begin{tabular}{lr}
\multicolumn{2}{c}{ COMPLICATIONS OF SURGERY } \\
Severe \\
Pulmonary embolus & $1 \%$ \\
Mild & \\
Stomal obstruction & $4 \%$ \\
Wound sepsis & $1 \%$ \\
Pneumonia or atalectasis & $8 \%$ \\
Thrombophlebitis & $1 \%$ \\
Total & $15 \%$ \\
Mortality of surgery in 100 cases from & $1 \%$ \\
pulmonary embolus & $1 \%$
\end{tabular}

which resulted in the only death in the series. Other complications were mild, and included four cases of transitory stomal obstruction, one case of superficial wound sepsis, eight cases of pneumonia or atelectases (all successfully treated by physiotherapy, coughing, and/or antibiotics), and one case of femoral thrombophlebitis.

\section{ACID STUDIES AND RECURRENCE OF ULCERATION}

The average resting free acid in 89 pre-operative patients was $46 \mathrm{mEq} . / \mathrm{l}$. with a range of 0 to 110
mEq./l. (Table III). This can be compared with an average resting free acid in 82 post-operative patients of $10 \mathrm{mEq}$. $/ \mathrm{l}$. with a range of 0 to $60 \mathrm{mEq}$. $/ 1$.

TABLE III

ACID STUDIES

\begin{tabular}{lll} 
Cases & $\begin{array}{c}\text { Pre-operative } \\
89\end{array}$ & $\begin{array}{c}\text { Post-operative } \\
82\end{array}$ \\
\hline Resting free acid (mEq./1.) & \multicolumn{1}{c}{$46(0-110)$} & $10(0-60)$ \\
Insulin response (\%) & 99 & 16
\end{tabular}

Of 82 patients, $99 \%$ had a positive pre-operative insulin response, while only $16 \%$ had a positive postoperative insulin response.

The relation between the post-operative insulin response and ulcer recurrence is interesting and significant (Table IV). In none of the 69 patients

TABLE IV

INSULIN RESPONSE AS MEASURE OF EFFECTIVENESS OF SURGERY

\begin{tabular}{lccc} 
Post-operative & Cases & No. & $\%$ \\
\hline Insulin Response & & Recurrent Ulcers & Recurrence \\
\hline Negative & 69 & 0 & 0 \\
Positive & 13 & 5 & 38
\end{tabular}

with a negative post-operative insulin response has there thus far been evidence of recurrent ulceration. Of the 13 cases with a positive post-operative insulin response, five cases $(38 \%)$ have shown evidence of recurrent ulceration. ${ }^{2}$ Their post-operative histories are briefly as follows:-

CASE 1 This 34-year-old man entered King's College Hospital with a four-year history of intractable duodenal ulceration. Acid studies revealed a pre-operative resting free acid level of $60 \mathrm{mEq}$./l. Post-operative resting free acid was recorded at $40 \mathrm{mEq} . / 1$. and the insulin response was strongly positive. Ulcer symptoms recurred six months port-operatively. Subtotal gastrectomy was performed and the patient has now been well for five years.

CASE 2 This 28-year-old man entered King's College Hospital with a five-year history of intractable duodenal ulceration. Acid studies revealed a pre-operative resting free acid level of $50 \mathrm{mEq}$./1. Post-operative resting free acid was recorded at $20 \mathrm{mEq}$. $/ 1$. and the insulin response was strongly positive. Three years post-operatively the patient noted recurrent ulcer symptoms. He was treated with antacids and diet and is doing well one and a half years after recurrence of symptoms.

CASE 3 This 29-year-old man entered King's College Hospital with a six-year history of intractable duodenal

${ }^{2}$ In one of them the drainage operation was a pyloroplasty. 
ulceration. Acid studies revealed a pre-operative resting free acid level of $70 \mathrm{mEq}$./1. Post-operative resting free acid was recorded at $30 \mathrm{mEq} . / \mathrm{l}$. and the insulin response was strongly positive. Two years post-operatively he noted recurrence of ulcer symptoms and gastro-duodenal bleeding; he was treated with antacids and diet and is doing well five years after recurrent trouble.

CASE 4 This 26-year-old man entered King's College Hospital with a history of intractable duodenal ulceration. Acid studies revealed a pre-operative resting free acid level of $60 \mathrm{mEq}$./l. Post-operative resting free acid was recorded at $60 \mathrm{mEq} . / \mathrm{l}$. and the insulin response was strongly positive. One and a half to two and a half years post-operatively, the patient noted recurrent ulcer symptoms and gastroduodenal bleeding; he was treated with diet and antacids, and is now doing fairly well five years after his last recurrent symptoms.

CASE 5 This 31-year-old man entered King's College Hospital with a five-year history of intractable duodenal ulceration. Acid studies revealed a pre-operative resting free acid level of $50 \mathrm{mEq}$./1. Post-operative resting free acid was recorded at $20 \mathrm{mEq}$./1. and the insulin response was moderately positive. One year after surgery he noted recurrence of ulcer symptoms. He was treated with diet and antacids and is doing fairly well two and a half years after recurrence.

\section{RESPONSES TO ENQUIRIES}

WAS THE OPERATION A SUCCESS? All patients were asked whether they considered their operation a success, and 96 of the 99 living patients said yes. The three patients who said no all had recurrent ulcers. (The two additional patients with recurrent ulcer disease thought their operation was a success, because they felt much better and more able to control their symptoms with diet and medication.)

FULL DAY's wORK Of the 99 living patients, 96 are now doing a full day's work-as much or more work than they were doing pre-operatively at a time when they felt well. There are three patients who are unable to do a full day's work, two because of recurrent ulcer symptoms and one because of 'general ill health', as was present before his operation.

SYMPTOMS As regards post-operative symptoms (Table V), $6 \%$ of the patients reported discomforts suggestive of the dumping syndrome ( $5 \%$ very mild, $1 \%$ moderate). In the 'mild' cases the symptoms were vasomotor in type, and in the one 'moderate' case bilious vomiting was the predominant feature. In none were the symptoms severe enough to keep the patient from doing a full day's work (five gastroenterostomy, one pyloroplasty).
TABLE V

POST-OPERATIVE SYMPTOMS RELATED TO SURGERY

\begin{tabular}{lccc} 
& $\begin{array}{l}\text { Mild } \\
(\%)\end{array}$ & $\begin{array}{l}\text { Moderate } \\
(\%)\end{array}$ & $\begin{array}{l}\text { Severe } \\
(\%)\end{array}$ \\
\hline $\begin{array}{l}\text { Dumping } \\
\text { Diarrhoea }\end{array}$ & 5 & 1 & 0 \\
Flatulence or OCC indigestion 15 & 2 & 0 \\
& 15 & 0 & 0
\end{tabular}

Fifteen had diarrhoea (13 mild, 2 moderate). In no case was the diarrhoea severe enough for the patient to consider this a serious problem, or to keep the patient from doing a full day's work. (Two of the mild cases had a pyloroplasty.)

Fifteen of the patients had various complaints of flatulence and indigestion, all of a mild degree (one pyloroplasty, 14 gastroenterostomy).

WEIGHT Twenty-three per cent. of the patients gained weight. The average gain was $14 \mathrm{lb}$., with a range of 2 to $56 \mathrm{lb}$. Thirteen of the patients lost weight. The average loss was $9 \mathrm{lb}$., with a range of 2 to $24 \mathrm{lb}$. (Table VI).

TABLE VI

CHANGE IN WEIGHT SINCE SURGERY

$\begin{array}{lc}\begin{array}{l}\text { Gain in weight } \\ \text { Average gain } \\ \text { Range }\end{array} & 14 \mathrm{lb} . \\ \begin{array}{l}\text { Loss in weight } \\ \begin{array}{l}\text { Average loss } \\ \text { Range }\end{array}\end{array} & 23 \% \mathrm{lb} . \\ & 9 \mathrm{lb} . \\ \end{array}$

ANAEMIA Only one patient has been noted to be anaemic. This patient has required iron to maintain her haemoglobin at $80 \%$.

\section{DISCUSSION}

A recurrence rate of $5 \%$ with a 4.9 year average follow-up compares favourably with the recurrence rate after subtotal gastrectomy or after vagotomy alone. Statistics compiled by the Committee on Peptic Ulcer of the American Gastroenterological Association (Sandweiss et al., 1952) revealed a recurrence of ulcer symptons in $4.3 \%$ of patients after subtotal gastrectomy. This is similar to the recurrence rate of $4.2 \%$ after subtotal gastrectomy recently reported by Armstrong and Penick (1960). Brooks and Moore (1953) found a recurrence rate of $13 \%$ after vagotomy alone and Sandweiss et al. (1952) have reported even higher recurrence rates following this procedure. The results of vagotomy and a gastric drainage procedure, however, do not match the extraordinarily low incidence of recurrent ulceration associated with hemigastrectomy and 
vagotomy. Farmer and Smithwick (personal communication) and Edwards, Herrington, Stephenson, Carlson, Phillips, Cate, and Scott (1957) found a recurrence rate after this procedure of $0.9 \%$ and $0 \%$ respectively.

The relationship of recurrent ulcer disease with the completeness of vagotomy as indicated by the insulin response test is significant. No case in this series with a negative insulin response postoperatively has thus far developed a recurrent ulcer, while $38 \%$ of the cases with a positive post-operative insulin response have suffered from recurrent disease.

Undesirable side-effects following vagotomy and a gastric drainage procedure are neither frequent nor severe. Only $6 \%$ of our patients developed symptoms consistent with the dumping syndrome and in only one case was this of even moderate severity. These results compare favourably with a reported $11 \%$ to $33 \%$ incidence of the dumping syndrome after subtotal gastrectomy (Hayes, 1955; Jordan, 1958; Armstrong and Penick, 1960) and of $23.1 \%$ after hemigastrectomy and vagotomy (Edwards et al., 1957).

The absence of side-effects after vagotomy and a drainage procedure is also reflected by weight statistics, which show that more of our patients gained than lost weight after operation. Even more significant is the fact that of the 13 patients who lost weight only two lost more than one stone, and in none was weight loss a serious problem. In contrast, reported results following subtotal gastrectomy indicate an approximate $40 \%$ incidence of weight loss (Muir, 1949; Ivy, Grossman, and Bachrach, 1950 ); in about $18 \%$ to $22 \%$ (Muir, 1949; Armstrong and Penick, 1960), the weight loss exceeded one stone. Excessive weight loss may also be a problem after hemigastrectomy and vagotomy. Farmer and Smithwick (personal communication) recently found that a moderate or severe weight loss occurred in $3.2 \%$ of their patients after this operation.

Vagotomy and a gastric drainage procedure is associated with a high incidence of post-operative diarrhoea. It occurred in $\mathbf{1 5}$ of our patients, but in only two cases was it more than mild in degree, and in none was it so severe as to incapacitate. Reported results following subtotal gastrectomy reveal a lesser incidence of diarrhoea, which is usually mild in degree (Sandweiss et al., 1952). (The incidence of post-operative symptoms was on a similar scale after pyloroplasty as after gastroenterostomy, but the number of patients submitted to the former are too small to assess the relative merits of the two procedures from the clinical standpoint.)

Finally, the operation of vagotomy and gastric drainage is usually technically easy and quick to perform and thus avoids the complications, immediate and remote, which are inherent in the operation of partial gastrectomy. The absence of severe operative complications, the low operative mortality coupled with an incidence of side effects and recurrent ulceration, which compares favourably with alternative forms of surgical treatment, strengthen our belief that this procedure amply justifies itself as a method of treatment for chronic duodenal ulceration.

\section{SUMMARY AND CONCLUSIONS}

1 One hundred patients with chronic duodenal disease treated by vagotomy and a gastric drainage operation are reviewed.

2 Vagotomy and a gastric drainage operation is usually an easier and safer procedure than partial gastrectomy, and is associated with a lower operative mortality and morbidity.

3 Recurrent symptoms occurred only in those patients in whom the post-operative insulin response indicated that vagotomy had been incomplete. It is therefore essential that vagotomy should be complete.

4 The long-term post-operative side effects of this procedure are less frequent and less debilitating than those associated with operations for chronic duodenal ulceration which entail removal of part of the stomach.

\section{A P P E N D I X}

\section{RESTING FREE AND TOTAL ACID STUDIES AND INSULIN RESPONSE}

These tests are carried out after the patient has been starved from 6 p.m. to 9 p.m. A Ryle's tube is passed into the stomach through the nose, and 5 to $10 \mathrm{ml}$. of gastric contents withdrawn at hourly intervals for 12 hours. Fifteen to 20 units of regular insulin are then given intravenously. After 15 minutes, further quarter hourly specimens of gastric contents are withdrawn for one hour. The Ryle's tube is then removed and the patient given 50 grams of glucose.

Free and total acid levels are determined on all samples by titration using thymol blue as indicator.

\section{REFERENCES}

Armstrong, R. A., and Penick, R. M. (1960). Surgical treatment of benign peptic ulcer. Ann. Surg., 152, 109-118.

Brooks, J. R., and Moore, F. D. (1953). Vagotomy for duodenal ulcer. A final survey after 10 years. New Engl. J. Med., 249, 1089-1097. 
Edwards, L. W., Herrington, J. L. Jr., Stephenson, S. E. Jr., Carlson, R. I., Phillips, R. J. Jr., Cate, W. R. Jr., and Scott, H. W. Jr. (1957). Duodenal ulcer: Treatment by vagotomy and removal of the gastric antrum. Ann. Surg., 145, 738-752.

Hayes, M. A. (1955). The dietary control of the postgastrectomy "dumping syndrome". Surgery, 37, 785-793.

Hollander, F. (1946). The insulin test for the presence of intact nerve fibers after vagal operations for peptic ulcer. Gastroenterology, 7, 606-614.

(1948). Laboratory procedures in the study of vagotomy (with particular reference to the insulin test). Ibid, 11, 419-425.

Ivy, A. C., Grossman, M. I., and Bachrach, W. H. (1950). Peptic Ulcer. Blakiston, Philadelphia.
Jordan, G. L. (1958). Treatment of the dumping syndrome. J. Amer. med. Ass., 167, 1062-1066.

Muir, A. (1949). Postgastrectomy syndromes. Brit. J. Surg., 37, 165-178.

Sandweiss, D. J., Barborka, C. J., Bockus, H. L., Ivy, A. C., Jordan, S. M., Miller, T. G., Palmer, W. L., Wangensteen, O. H., Ruffin, J. M., Aaron, A. H., Hollander, F., Thomas, J. E., Walters, W., Moore, F. D., Winkelstein, A., Brooks, F. P., and Lorge, I. (1952). Report of the Committee on Surgical Procedures of the National Committee on Peptic Ulcer of the American Gastroenterological Association on Study of Vagotomy, Study of Gastric Resection, Comparative Study of Vagotomy and Gastric Resection. Gastroenterology, 22, 295-499. 
Biopsies of the mucosa of the small intestine of 22 patients were subjected to light and electron microscopic studies. The patients were grouped into "controls', coeliac disease, and idiopathic steatorrhoea, and in the last two groups the clinical condition and therapeutic progress was recorded. Electron microscopic studies were directed mainly towards the microvilli of the surface epithelium. It was found that the latter were decreased in height in coeliac disease and idiopathic steatorrhoea and showed greater irregularity in shape and spacing. A good correlation existed between the light microscope appearances of villous atrophy and decrease in surface cell height and the electron microscope findings of microvillous abnormalities.

Our thanks are due to the many physicians who kindly referred their patients to us for investigation, to Dr. R. A. B. Drury and Mr. J. E. Mayhew for the histology, and Mrs. S. Roberts for preparing the electron microscopy sections.

One of us (M.S.) is working with a grant from the Medical Research Council to which grateful acknowledgements are herewith made.
Anderson, C. M. (1960). Histological changes in the duodenal mucosa in coeliac disease. Arch. Dis. Childh., 35, 419.

Brettauer, J., and Steinach, S. (1857). Untersuchungen über das Cylinderapithelium der Darmzotten und seine Beziehung zur fettresorption. S.-B. Akad. Wiss. Wien, math.-nat. Kl., 23, 303.

Doniach, I., and Shiner, M. (1957). Duodenal and jejunal biopsies II. Histology. Gastroenterology, 33, 71.

Glauert, A. M., Rogers, G. E., and Glauert, R. H. (1956). A new embedding medium for electron microscopy. Nature (Lond.), $178,803$.

Granger, B., and Baker, R. F. (1949). Electron microscope investigation of the striated border of intestinal epithelium. Anat. Rec., $103,459$.

Hartman, R. S., Butterworth, C. E., Hartman, R. E., Crosby, W. H., and Shirai, A. (1960). An electron microscope investigation of the jejunal epithelium in sprue. Gastroenterology, 38, 506.

Palade, G. E. (1952). A study of fixation for electron microscopy. J. exp. Med., 95, 285.

Palay, S. L., and Karlin, L. J. (1959). An electron microscopic study of the intestinal villus. I. The Fasting animal. J. biophys. biochem. Cytol., 5, 363.

Rubin, C. E., Brandborg, L. L., Phelps, P., Taylor, H. C. Jr., Murray, C.V., Stemler, R., Howrie, C., and Volwiler, W. (1960). Studies in coeliac disease II. Gastroenterology, 38, 517.

Shiner, M. (1956). Duodenal biopsy. Lancet, 1, 17 and 85.

(1960a). Coeliac disease. Gut, 1, 48.

- (1960b). Histopathology in Coeliac Disease. Proceedings of the International Congress of Gastroenterology, Leyden, Holland, April 20-24. In the press.

Gastroenterology, 38, 419.

Zetterquist, H.(1956). The Ultrastructural Organisation of the Columnar Absorbing Cells of the Mouse Jejunum. Thesis from the Department of Anatomy, Karolinska Institute, Stockholm, Sweden.

—, and Hendrix, T. R. (1960). Bull. Johns Hopk. Hosp., 106, 240.

\section{CORRECTION}

In Table I of the paper entitled 'A clinical appraisal of the treatment of chronic duodenal ulcer by vagotomy and gastric drainage operation' by W. Gerald Austen and Harold C. Edwards on page 158 of the June issues, the word 'pyloroplasty' has been incorrectly repeated. The relevant line of Table I should read:-

Type of operation performed with vagotomy

Gastroenterostomy $\quad 90$

Pyloroplasty 